\title{
Regulasi Emosi dan Dukungan Sosial: Sebagai Prediktor Ide Bunuh Diri Mahasiswa
}

\author{
Syafira Triesna Adinda ${ }^{1}$, Endang Prastuti ${ }^{2 *}$ \\ Universitas Negeri Malang \\ ${ }^{1}$ syafiradinda08@gmail.com, ${ }^{2}$ endang.prastuti.fppsi@um.ac.id \\ *Correspondence
}

Article Information:

Received 19 January 2021

Revised 01 April 2021

Accepted 29 May 2021

Keywords:

Collage student; Emotion regulation; Social support;

Suicidal ideation

Kata Kunci:

Dukungan social; Ide bunuh diri; Mahasiswa; Regulasi emosi
This study aims to know the effect of emotion regulation and social support towards suicidal ideation on college students. This research was based on preliminary data, which showed suicidal ideation that arose among college students. The subject of this study was 210 students of the State University of Malang. This study used descriptive-correlational research. The instrument used in this study was adapted from several measuring devices. There is Emotion Regulation Questionnaire (ERQ) developed by Gross, Interpersonal Support Evaluation List (ISEL) designed by Hoberman \& Cohen, and the Suicidal Ideation Questionnaire (SIQ) developed by PAR, Inc (Psychological Assessment Resource), which refers to the scale that was developed by Reynolds. The results show that (1) there is an effect of emotion regulation towards suicidal ideation with $\mathrm{t}$-count value $<0.05$ or by 0.000 (2) there is an effect of social support towards suicidal ideation with t-count value $<0.05$ or by 0.008 (3) there is an effect of regulation emotion and social support towards suicidal ideation with $\mathrm{f}$-count value $<0.05$ or by 0.000 , and $39.62 \%$ effective contribution. Based on these results, it can conclude that social support and emotional regulation influence the emergence of suicidal ideation in students.

Abstrak
Penelitian ini bertujuan untuk mengetahui pengaruh regulasi emosi dan dukungan sosial terhadap ide bunuh diri pada mahasiswa. Topik penelitian ini diambil berdasarkan hasil dari data awal yang menunjukkan adanya fenomena mengenai ide bunuh diri yang banyak muncul di kalangan mahasiswa. Penelitian ini melibatkan subjek 210 orang mahasiswa di Universitas Negeri Malang. Penelitian ini menggunakan teknik penelitian kuantitatif dengan metode deskriptif-korelasional. Instrumen penelitian ini menggunakan adaptasi dari tiga alat ukur yaitu adaptasi Emotion Regulation Questionnaire (ERQ) yang dikembangkan oleh Gross, adaptasi Interpersonal Support Evaluation List (ISEL) yang dikembangkan oleh Hoberman \& Cohen, dan adaptasi Suicidal Ideation Questionnaire (SIQ) yang dikembangkan oleh PAR, Inc (Psychological Assesment Resource) yang didasarkan dari skala yang dikembangkan oleh Reynolds. Hasil penelitian terhadap mahasiswa (1) terdapat pengaruh antara regulasi emosi terhadap ide bunuh diri dengan t- 
hitung < 0.05 , yaitu sebesar 0.000 (2) terdapat pengaruh antara dukungan sosial terhadap ide bunuh diri dengan nilai t-hitung < 0.05 , yaitu sebesar 0.008 (3) terdapat pengaruh antara regulasi emosi dan dukungan sosial terhadap ide bunuh diri dengan nilai f hitung $<0.05$, yaitu 0.000 dan memiliki sumbangan efektif sebesar $39.62 \%$. Berdasarkan hasil tersebut maka dapat disimpulkan bahwa dukungan sosial dan regulasi emosi memiliki pengaruh terhadap munculnya ide bunuh diri pada mahasiswa.

\section{PENDAHULUAN}

Di kalangan mahasiswa, suicidal ideation ternyata bukan fenomena yang baru, bahkan semakin merebak akhir-akhir ini. Penelitian yang dilakukan pada mahasiswa (Wilcox dkk., 2011) menunjukkan bahwa selama masa pendidikan di Universitas, sebanyak $12 \%$ mahasiswa mengalami atau memiliki pemikiran atau ide untuk melakukan bunuh diri dan $2.6 \%$ diantaranya memiliki ide bunuh diri yang berlangsung terus menerus. Data lain yang ditunjukkan oleh American College Health Association menyatakan bahwa 3.7\% mahasiswa secara serius mencoba untuk melakukan bunuh diri dalam kurun waktu 12 bulan terakhir, dan $1.5 \%$ berpikir untuk mengakhiri hidupnya dalam 2 minggu terakhir berdasar pada waktu saat pengambilan data penelitian tersebut (Pereira \& Cardoso, 2015).

Berdasarkan survei awal yang dilakukan penulis melalui Instagram (Desember 2019), memberikan informasi bahwa dari 91 orang yang memberikan voting (semua peserta telah disaring dengan ketentuan mahasiswa yang tersebar di seluruh Universitas di kota Malang) tentang ide bunuh diri, $30 \%$ orang pernah berkeinginan untuk melakukan bunuh diri (16\% orang diantaranya telah melakukan percobaan bunuh diri). Respon responden menjawab pertanyaan mengenai kejadian stres berat atau depresi: terdapat $86 \%$ orang yang mengaku pernah mengalaminya, dan pada pertanyaan mengenai menyakiti tubuh sendiri (self-harm) $36 \%$ orang diantaranya mengaku pernah melakukannya. Merujuk pada studi awal tersebut, dapat diketahui bahwa banyak kejadian yang berkaitan dengan perilaku bunuh diri yang terjadi. Wawancara lanjutan lalu dilakukan kepada beberapa partisipan (yang mengikuti pada proses pengambilan data awal yang dilakukan melalui Instagram) khususnya responden yang melakukan self harm, serta memiliki dan atau memunculkan ide untuk melakukan bunuh diri atau percobaan bunuh diri. Wawancara lanjutan difokuskan pada pertanyaan: apa yang dirasakan oleh partisipan akhirnya melakukan self harm dan atau memiliki ide bunuh diri serta melakukan percobaan bunuh diri. Hasilnya ditemukan bahwa partisipan mengatakan bahwa saat mereka berada dalam posisi tertekan, mereka merasa tidak dapat menyelesaikan masalah dan emosi yang begitu kuat dirasakan. Mereka merasa ingin segera mengakhiri rasa tertekan (beberapa partisipan menjelaskan perasaan yang muncul seperti sedih, stres, marah) yang muncul saat mereka merasa memiliki beban berat yang diakibatkan oleh permasalahan yang terjadi dalam hidupnya. Partisipan juga menyebutkan bahwa mereka merasa tidak mendapatkan dukungan dari orang sekitarnya (keluarga, teman, pasangan) sehingga akhirnya mereka memiliki kekuatan untuk 
akhirnya melukai diri, atau berpikir untuk melakukan bunuh diri, dan bahkan melakukan percobaan bunuh diri.

Kondisi dan situasi yang menekan yang terjadi dalam kehidupan seseorang dapat memunculkan reaksi emosi baik itu positif maupun negatif yang dapat menyebabkan individu mengalami tekanan berat yang dapat mengarah pada depresi dan bahkan perilaku bunuh diri. Beberapa penelitian menyebutkan bahwa terdapat beberapa faktor resiko yang dapat dihubungkan dengan perilaku bunuh diri yakni: depresi, tidak adanya atau rendahnya kemampuan koping, tingginya perilaku menghindar dari stressor dan kurangnya hubungan sosial yang dekat (John \& Gross, 2004). Akan tetapi, tidak semua orang yang mengalami emosi negatif akan berlanjut pada perilaku bunuh diri. Ketika dihadapkan pada situasi yang memunculkan emosi negatif, beberapa orang dapat mengatasi dan mengatur emosinya sehingga tidak mengarah ke perilaku bunuh diri, akan tetapi beberapa orang lainnya ketika kurang dapat meregulasi emosi dapat mengarah pada dorongan dan gagasan untuk melakukan bunuh diri (Bazrafshan dkk., 2014).

Regulasi emosi merupakan kesatuan proses pengaturan yang bisa digunakan untuk mengalihkan emosi dengan tujuan untuk memodifikasi, mengubah dan mengurangi durasi/waktu dari suatu respon afektif tertentu (Miranda dkk., 2012). Regulasi emosi memiliki kaitan dengan perilaku bunuh diri artinya ketika seseorang gagal dalam mengadopsi respon emosional tertentu, maka individu akan mengalami kegagalan dalam penerapan regulasi emosi, selanjutnya akan memprediksi adanya pemikiran untuk melakukan bunuh diri (Ong \& Thompson, 2019a). Perilaku bunuh diri merupakan upaya individu untuk menghilangkan atau menghindari emosi negatif yang dialami, dikarenakan ketidakmampuan individu meregulasi emosi ketika menghadapi distress emosional (Rajappa dkk., 2012a). Dengan demikian, regulasi emosi merupakan proses yang sangat penting dalam kehidupan seseorang terkait dengan pemikiran (ide) bunuh diri.

Selain regulasi emosi, dukungan sosial merupakan faktor lain yang dapat mempengaruhi ide bunuh diri. Pentingnya dukungan sosial secara konsisten muncul pada penelitian-penelitian yang membahas mengenai perilaku suicidal dan perkembangan psikopatologis. Beberapa teori seperti the sociological theory of suicide, the psychache theory of suicide, dan the interpersonal-psychological theory of suicide (IPTS) menunjukkan bahwa dukungan sosial dan relasi interpersonal yang kurang memadai dapat meningkatkan resiko munculnya ide melakukan bunuh diri maupun percobaan bunuh diri (Miller dkk., 2015).

Dukungan sosial menjadi salah satu faktor penting yang dapat membantu individu dalam menjalani kehidupan personalnya. Hal ini dikarenakan dalam menjalani kehidupan, individu akan berinteraksi dan saling membutuhkan dalam lingkungan sosialnya. Dukungan sosial diartikan sebagai semua bentuk dukungan yang disediakan individu dan kelompok lain yang membantu seorang individu mengatasi hidup (Reber \& Reber, 2010). Jadi, dapat dikatakan bahwa seseorang membutuhkan dukungan sosial untuk membantu mengatasi masalah-masalah yang mungkin muncul dalam 
kehidupannya. Relevan dengan hal ini, dukungan social merupakan faktor primer yang menyebabkan munculnya ide bunuh (Klonsky \& May, 2015). Dikaitkan dengan kehidupan mahasiswa, kurangnya dukungan sosial dalam tahap perkembangan menjadi salah satu faktor resiko adanya ide bunuh diri (Kimbrough dkk., 1996).

Penelitian lain menguatkan bahwa ada hubungan negatif antara dukungan sosial dengan ide bunuh diri, artinya dukungan sosial yang rendah akan meningkatkan keparahan ide bunuh diri. Dengan demikian, dukungan sosial dapat membantu seorang individu mengatasi masalah-masalah hidup, yang penuh stres kemudian dalam jangka panjang dapat mengarah pada munculnya ide bunuh diri (Salsabhilla \& Panjaitan, 2019). Berdasarkan penelitian tersebut menguatkan bahwa dukungan sosial dapat menjadi salah satu faktor yang mempengaruhi muncul atau tidaknya ide untuk melakukan bunuh diri.

Merujuk pada telaah literatur, membuktikan pentingnya peran regulasi kaitannya dengan munculnya ide bunuh diri, begitu juga dengan kontribusi dukungan sosial, khususnya pada responden remaja, namun demikian belum banyak penelitian yang menguji peran dua prediktor yakni: regulasi emosi dan dukungan sosial, terkhusus dukungan dari keluarga dalam memprediksi pikiran bunuh diri pada responden mahasiswa di Universitas Negeri Malang. Hal lain yang menguatkan pentingnya penelitian ini adalah merujuk pada data awal pada responden mahasiswa menunjukkan bahwa saat subjek berada dalam posisi tertekan dan tidak dapat menyelesaikan masalah, diikuti dengan emosi yang kuat, kemudian muncul pikiran untuk mengakhiri rasa tertekan, sedih, stres dan marah Hal lain yang memperkuat adalah adanya perasaan tidak memperoleh dukungan dari orang sekitarnya (keluarga, teman, pasangan) sehingga menguatkan subjek lalu memiliki keinginan untuk melukai diri atau berpikir untuk melakukan bunuh diri bahkan melakukan percobaan bunuh diri. Oleh karena upaya pemecahan terhadap fenomena ini perlu dilakukan berbasis penelitian ilmiah. Temuan yang dihasilkan dapat menjadi masukan bagi Lembaga untuk melakukan upaya preventif mencegah munculnya ide bunuh diri pada mahasiswa.

Tujuan dari penelitian ini adalah untuk (1) mendeskripsi regulasi emosi, dukungan sosial, dan ide bunuh diri pada mahasiswa, (2) menguji pengaruh regulasi emosi terhadap ide bunuh diri pada mahasiswa, (3) menguji pengaruh dukungan sosial terhadap ide bunuh diri pada mahasiswa, (4) menguji pengaruh regulasi emosi dan dukungan sosial terhadap ide bunuh diri pada mahasiswa, dan (5) menguji sumbangan efektif regulasi emosi dan dukungan sosial sebagai prediktor ide bunuh diri pada mahasiswa.

\section{METODE}

Penelitian ini menggunakan pendekatan kuantitatif karena bertujuan untuk menguji suatu teori, menyajikan fakta, dan menunjukkan hubungan antar variabel untuk mengembangkan suatu konsep. Analisis data dilakukan dengan analisis statistik deskriptif, yaitu dengan mendeskripsikan atau memberikan gambaran terhadap objek yang diteliti melalui data sampel atau populasi sebagaimana adanya, tanpa melakukan 
analisis dan membuat kesimpulan yang berlaku untuk umum. Analisis data dilakukan dengan analisis regresi ganda, dimana analisis ini dilakukan apabila peneliti bermaksud untuk meramalkan keadaan (naik turunnya) variabel dependen (kriterium) bila dua atau lebih variabel independen sebagai prediktor dimanipulasi (dinaik turunkan nilainya) (Sugiyono, 2018). Penelitian ini terdiri dari dua variabel independen yaitu regulasi emosi $\left(\mathrm{X}_{1}\right)$ dan dukungan sosial $\left(\mathrm{X}_{2}\right)$ dan variabel dependen yaitu ide bunuh diri (Y). Penelitian ini akan meneliti mengenai peristiwa ide bunuh diri pada mahasiswa tingkat akhir yang akan dijelaskan dengan melihat pengaruh regulasi emosi dan dukungan sosial pada mahasiswa tersebut secara sistematis dan faktual berdasarkan data.

Populasi pada penelitian ini adalah mahasiswa S1 di Universitas Negeri Malang angkatan 2016 dari delapan Fakultas, total berjumlah 2830 mahasiswa. Berdasarkan rumus Slovin mengenai penentuan jumlah sampel jika populasi diketahui jumlahnya (Sugiyono, 2018) dengan taraf kesalahan sebesar 5\% diperoleh sampel sejumlah 210 orang. Teknik sampling yang digunakan pada penelitian ini adalah teknik sampling insidental, yaitu teknik penentuan sampel berdasarkan kebetulan, siapa saja yang secara kebetulan/insidental bertemu dengan peneliti dapat digunakan dengan sampel, yang dirasa memenuhi karakteristik atau dirasa cocok sebagai sumber data (Sugiyono, 2016).

Penelitian ini menggunakan skala psikologis dengan tiga instrumen untuk mengukur variabel yang diteliti. Skala regulasi emosi menggunakan alat ukur Emotion Regulation Questionnaire (ERQ) yang dikembangkan oleh (Gross \& John, 2003), terdiri dari 10 aitem yang didasarkan atas dua aspek, yaitu Cognitive Reappraisal (salah satu bentuk regulasi emosi yang berorientasi secara kognitif) dimana seseorang mencoba untuk memikirkan sebuah situasi dimana respons emosionalnya dapat diubah atau diatur dan melibatkan kerja secara kognitif dimana seseorang akan mengubah emosinya yang negatif menjadi positif, dan Expressive Suppression (bentuk regulasi emosi yang berorientasi pada perilaku) dimana seseorang mengurangi perilaku emosional ekspresifnya ketika emosi dibangkitkan oleh kejadian (cue emosional).

Skala dukungan sosial menggunakan alat ukur International Support Evauation List (ISEL) yang dikembangkan oleh (Cohen \& Hoberman, 1983), terdiri dari 40 aitem yang didasarkan atas empat aspek yang terdiri atas; (1) Dukungan emosional (emotional or esteem support) termasuk didalamnya menyampaikan empati, kepedulian, kekhawatiran, penghargaan positif (positive regard), dan penentraman hati dengan adanya rasa dimiliki dan dicintai yang dirasakan penerima dukungan terhadap pemberi dukungan, (2) Dukungan nyata atau instrumental (tangible or instrumental support), di dalamnya melibatkan bantuan secara langsung berupa tindakan nyata, (3) Dukungan informasional (informational support), termasuk di dalamnya seperti memberikan nasihan, petunjuk, saran, ataupun timbal balik atau feedback tentang bagaimana seseorang bertingkah laku, dan (4) Dukungan persahabatan (companionship support), merujuk pada ketersediaan individu untuk menghabiskan waktu dengan seseorang (yang membutuhkan dukungan), termasuk memberikan perasaan bahwa seseorang (yang 
membutuhkan dukungan) tersebut adalah bagian dari suatu kelompok tertentu yang mau berbagi ketertarikan dan aktivitas sosial dalam lingkungannya.

Skala ide bunuh diri menggunakan alat ukur Suicidal Ideation Questionnaire (SIQ) yang dikembangkan oleh PAR, Inc (Psychological Assesment Resource) yang didasarkan dari skala yang dikembangkan oleh (Reynolds \& Mazza, 1999a) dan terdiri atas 15 aitem. Skala ide bunuh diri didasarkan pada tahapan munculnya ide bunuh diri yang dibagi dalam tiga tahapan, yaitu : (1) munculnya ide untuk melakukan bunuh diri akibat rasa sakit fisik dan psikis yang dikombinasikan dengan hilangnya kemampuan untuk mencari penyelesaian rasa sakit tersebut (2) ide menjadi lebih kuat karena individu terkait tidak bisa berbagi dan atau menceritakan rasa sakitnya kepada relasi (sesuatu atau seseorang yang dapat menjadi alasan kuat untuk tetap hidup) (3) hanya muncul ketika individu memiliki kesiapan, baik fisik maupun psikis, dan ketersediaan alat yang diperlukan dan dapat digunakan untuk melakukan percobaan bunuh diri.

Ketiga instrumen penelitian dilakukan proses adaptasi dengan mengikuti langkalangkah adaptasi Back Translation. Dijelaskan dalam (Beaton dkk., 2000), terdapat lima tahap dalam proses adaptasi yaitu: (1) Translasi, proses penerjemahan alat ukur dari bahasa asli alat ukur (semula berbahasa inggris) menjadi bahasa dimana alat ukur tersebut akan digunakan (dalam hal ini ditranslasikan dalam bahasa indonesia). Proses translasi dilakukan oleh dua orang ahli bahasa, (2) Sintesa, proses mensintesakan atau penggabungan dua hasil translasi menjadi satu bentuk translasi, (3) Back Translation, proses translasi kembali dari bahasa indonesia ke bahasa inggris dengan tujuan untuk melihat kesesuaian kata dari hasil penggabungan translasi dari tahap sebelumnya, (4) Expert Judgement, pengujian hasil translasi, penilaian ekuivalensi bahasa dan konsep yang dinilai peraitem, (5) Pretesting Item, tahapan uji coba aitem kepada subjek yang setara.

Uji validitas ketiga instrumen terdiri dari dua langkah. Langkah pertama dilakukan uji validitas isi (content validity) oleh ahli psikologi untuk memberikan penilaian dengan menggunakan rentang nilai 1 (paling rendah) hingga 5 (paling tinggi). Penilaian dilakukan dengan menggunakan bantuan aplikasi Microsoft Excel dan diperoleh hasil bahwa seluruh aitem memiliki validitas isi yang baik dengan rentang nilai $0,75-1,00$ dan nilai $\mathrm{V} \geq 0,5$. Setelah itu dilakukan uji indeks diskriminasi aitem menggunakan Pearson Product Moment dengan bantuan SPSS 20.0 for Windows. Diperoleh data dari 40 responden, nilai $r$ tabel product moment dengan taraf signifikansi $5 \%$ adalah sebesar 0.312 .

Hasil uji validitas menunjukkan; (1) alat ukur regulasi emosi yang berjumlah 10 aitem, keseluruhan aitem valid dengan nilai $r$ terendah sebesar 0.341 dan nilai $r$ tertinggi sebesar 0.648 , (2) alat ukur dukungan sosial dari 40 aitem, terdapat 18 aitem yang valid dan 12 aitem gugur dengan nilai terendah sebesar 0.320 dan nilai $r$ tertinggi sebesar 0.560 , (3) alat ukur ide bunuh diri yang berjumlah 15 aitem, keseluruhan aitem valid dengan nilai $r$ terendah sebesar 0.449 dan nilai $r$ tertinggi sebesar 0.902 . Selanjutnya uji 
reliablitas menggunakan koefisien reliabilitas dari Alpha Cornbach dengan bantuan SPSS 20.0 for Windows. Didapatkan hasil reliabilitas dari skala regulasi emosi sebesar 0.631, skala dukungan sosial sebesar 0.783, Dengan demikian dapat disimpulkan ketiga alat ukur tersebut dinyatakan reliabel dan layak sebagai alat pengumpul data.

\section{HASIL PENELITIAN}

Data regulasi emosi diperoleh nilai minimum sebesar 29 dan nilai maksimum sebesar 79, dengan range sebesar 41, standar deviasi sebesar 9.493, dan mean sebesar 51.4. Regulasi emosi dikategorisasikan dengan melihat nilai mean dan standar deviasi. Tabel kategorisasi untuk regulasi emosi adalah sebagai berikut:

Tabel 1. Kategorisasi Regulasi Emosi Pada Mahasiswa

\begin{tabular}{cccc}
\hline Interval & Kategorisasi & Frekuensi & Persentase (\%) \\
\hline$>50$ & Tinggi & 127 & $60.48 \%$ \\
$30-50$ & Sedang & 82 & $39.04 \%$ \\
$<30$ & Rendah & 1 & $0.48 \%$ \\
Total & & & $100 \%$ \\
\hline
\end{tabular}

Berdasarkan hasil analisis kategorisasi regulasi emosi, dapat dilihat bahwa subjek memiliki kategorisasi dalam kemampuan regulasi emosi yang beragam dengan rincian sebanyak 1 subjek $(0.48 \%)$ termasuk dalam kategori rendah, sementara itu 82 subjek (39.04\%) termasuk dalam kategori sedang dan 127 (60.48\%) subjek termasuk dalam kategori tinggi.

Tabel 2 berikut memberikan informasi bahwa: sebanyak 208 mahasiswa (99.91\%) memiliki kemampuan regulasi emosi dengan startegi cognitive reappraisal dan sebanyak 2 orang mahasiswa $(0.9 \%)$ menggunakan regulasi emosi dengan strategi expressive suppression.

Tabel 2. Kategorisasi Aspek Regulasi Emosi Pada Mahasiswa

\begin{tabular}{ccc}
\hline Aspek & Frekuensi & Persentase (\%) \\
\hline Cognitive Reappraisal & 208 & $99,91 \%$ \\
Expressive Suppression & 2 & $0,9 \%$ \\
Total & & $100 \%$ \\
\hline
\end{tabular}

Data dukungan sosial diperoleh nilai minimum sebesar 10 dan nilai maksimum sebesar 54, dengan range sebesar 44, standar deviasi sebesar 10.584, dan mean sebesar 29,65. Dukungan sosial dikategorisasikan dengan melihat nilai mean dan standar deviasi. Tabel kategorisasi untuk dukungan sosial ditunjukkan pada tabel 3 sebagai berikut:

Tabel 3. Kategorisasi Dukungan Sosial yang Dirasakan Mahasiswa

\begin{tabular}{cccc}
\hline Interval Kelas & Kategorisasi & Frekuensi & Persentase $(\%)$ \\
\hline$>36$ & Tinggi & 50 & $23.81 \%$ \\
$18-36$ & Sedang & 131 & $62.39 \%$ \\
$<18$ & Rendah & 29 & $13.8 \%$ \\
Total & & & $100 \%$ \\
\hline
\end{tabular}


Berdasarkan hasil analisis kategorisasi dukungan sosial dalam tabel 3 dapat dilihat bahwa subjek mendapatkan dukungan sosial yang beragam dengan rincian sebagai berikut: sebanyak 29 subjek (13.8\%) termasuk dalam kategori rendah, 131 subjek (62.39\%) mendapatkan dukungan sosial termasuk dalam kategori sedang dan 50 subjek (23.81\%) mendapatkan dukungan sosial dalam kategori tinggi.

Sebanyak 78 orang subjek (37\%) mendapatkan dukungan sosial dalam bentuk appraisal support, 80 orang subjek (38\%) mendapatkan dukungan sosial dalam bentuk tangible support, 37 orang subjek (7\%) mendapatkan dukungan sosial dalam bentuk selfesteem support dan 15 orang subjek (8\%) mendapatkan dukungan sosial dalam bentuk belonging support.

Tabel 4. Kategorisasi Aspek Dukungan Sosial Yang Dirasakan Mahasiswa

\begin{tabular}{ccc}
\hline Aspek & Frekuensi & Persentase (\%) \\
\hline Appraisal Support & 78 & $37 \%$ \\
Tangible Support & 80 & $38 \%$ \\
Self-Esteem Support & 37 & $17 \%$ \\
Belonging Support & 15 & $8 \%$ \\
Total & & $100 \%$ \\
\hline
\end{tabular}

Data ide bunuh diri diperoleh nilai minimum sebesar 0 dan nilai maksimum sebesar 29, dengan range sebesar 29, standar deviasi sebesar 6.998, dan mean sebesar 13.038. Ide bunuh diri dikategorisasikan dengan melihat nilai mean dan standar deviasi. Deskripsi dan kategorisasi ide bunuh diri disajikan pada tabel 5 berikut:

Tabel 5. Kategorisasi Ide Bunuh Diri

\begin{tabular}{cccc}
\hline Interval Kelas & Kategorisasi & Frekuensi & Persentase (\%) \\
\hline$>60$ & Tinggi & 35 & $16.66 \%$ \\
$20-60$ & Sedang & 136 & $64.77 \%$ \\
$<20$ & Rendah & 39 & $18.57 \%$ \\
Total & & & $100 \%$ \\
\hline
\end{tabular}

Berdasarkan hasil analisis kategorisasi ide bunuh diri ditunjukkan pada tabel 5 dapat dilihat bahwa subjek memiliki bentuk ide bunuh diri yang beragam dengan rincian sebagai berikut: sebanyak 39 subjek (18.57\%) termasuk dalam kategori rendah, 136 subjek $(64.77 \%)$ termasuk dalam kategori sedang dan 35 subjek (16.66\%) termasuk dalam kategori tinggi.

\section{Tabel 6. Kategorisasi Aspek Ide Bunuh Diri}

\begin{tabular}{lcc}
\hline \multicolumn{1}{c}{ Aspek } & Frekuensi & Persentase (\%) \\
\hline $\begin{array}{l}\text { Munculnya ide untuk melakukan bunuh diri akibat } \\
\text { rasa sakit fisik dan psikis yang dikombinasikan dengan } \\
\text { hilangnya kemampuan untuk mencari penyelesaian } \\
\text { rasa sakit tersebut }\end{array}$ & 28 & $14 \%$ \\
$\begin{array}{l}\text { Individu terkait tidak bisa berbagi dan atau } \\
\text { menceritakan rasa sakitnya kepada relasi (ide } \\
\text { menguat) }\end{array}$ & 164 & $80 \%$ \\
\hline
\end{tabular}


Individu memiliki kesiapan, baik fisik maupun psikis untuk melakukan percobaan bunuh diri (ide paling kuat).

Total

14

$6 \%$

$100 \%$

Tabel 6 menunjukkan bahwa: sebanyak 28 orang mahasiswa (14\%) berada pada tahapan awal untuk melakukan ide bunuh diri akibat rasa fisik dan psikis yang dikombinasikan dengan hilangnya kemampuan untuk mecari penyelesaian rasa sakit tersebut, 164 orang mahasiswa ( $80 \%$ ) memiliki ide bunuh diri pada tahapan selanjutnya dimana ide bunuh diri yang semakin menguat yang diakibatkan individu terkait tidak bisa berbagi rasa atau menceritakan rasa sakitnya kepada relasi, selanjutnya 14 orang mahasiswa (6\%) memiliki ide di tahapan terakhir dimana individu memiliki kesiapan, baik fisik maupun psikis untuk melakukan percobaan bunuh diri.

Sebelum dilakukan analisis, terlebih dahulu dilakukan uji normalitas sebaran. Hasil analisis ditunjukkan pada tabel 7 berikut:

Tabel 7. Hasil Uji Normalitas Kolmogorov Smirnov

\begin{tabular}{lccc}
\hline \multicolumn{4}{c}{ One-Sample Kolmogorov-Smirnov Test } \\
\hline Variabel & Regulasi Emosi & Dukungan & Ide Bunuh Diri \\
Asymp. Sig. (2-tailed) & .578 & Sosial & \\
\hline
\end{tabular}

Berdasarkan tabel 7 di atas, didapatkan hasil bahwa: dari seluruh variabel yaitu regulasi emosi 0.578, dukungan sosial 0.539, dan ide bunuh diri 0.560 dimana nilai Sig masing-masing yaitu $0.578>0.05,0.539>0.05$, dan $0.560>0.05$, sehingga data dapat dikatakan memiliki distribusi normal dan dapat dilakukan uji parametric. Uji asumsi selanjutnya adalah uji linieritas, disajikan pada tabel 8 di bawah ini:

Tabel 8. Hasil Uji Linieritas

\begin{tabular}{ccc}
\hline Variabel & Sig. \\
\hline Ide Bunuh Diri \& Regulasi Emosi & Deviation & 0.542 \\
Ide Bunuh Diri \& Dukungan Sosial & from Linearity & 0.111 \\
\hline
\end{tabular}

Berdasarkan tabel 8 hasil uji linieritas diperoleh hasil Deviation from Linearity dengan sig. sebesar 0.542 untuk variabel regulasi emosi terhadap ide bunuh diri dan sig sebesar 0.111 untuk variabel dukungan sosial dan ide bunuh diri. Berdasarkan hasil uji linearitas di atas dapat disimpulkan bahwa variabel ide bunuh diri memiliki linieritas terhadap variabel regulasi emosi dan dukungan sosial, karena telah memenuhi kaidah Sig. $>0.05$. Uji asumsi selanjutnya adalah uji multikolinieritas, disajikan pada table 9 berikut:

Tabel 9. Hasil Uji Multikolinieritas

\begin{tabular}{lcc}
\hline & \multicolumn{2}{c}{ Collinearity Statistics } \\
\hline Variabel & Tolerance & VIF \\
Regulasi Emosi & .561 & 1.782 \\
Dukungan Sosial & .561 & 1.782 \\
\hline
\end{tabular}


Berdasarkan tabel 9 hasil uji multikolinearitas didapatkan hasil bahwa: pada variabel regulasi emosi dan dukungan sosial memiliki nilai tolerance 0.561 artinya dengan nilai ini menunjukkan tidak terjadi multikolinearitas karena $0.561 \geq 0.10$ dan untuk nilai VIF diperoleh nilai sebesar 1,782 < 10 sehingga tidak terjadi multikoliniearitas. Dengan demikian, dapat disimpulkan bahwa tidak terjadi korelasi yang kuat antara variabel regulasi emosi dan dukungan sosial. Uji asumsi berikutnya adalah uji Heteroskedastisitas, ditunjukkan pada tabel 10 berikut:

Tabel 10. Hasil Uji Heteroskedastisitas

\begin{tabular}{lll}
\hline Variabel & $\mathrm{t}$ & Sig. \\
\hline Regulasi Emosi & -.613 & .540 \\
Dukungan Sosial & -.917 & .360 \\
\hline
\end{tabular}

Tabel 10 memberikan informasi bahwa: hasil uji heteroskedastisitas didapatkan hasil Sig. pada variabel regulasi emosi 0.540 dan dukungan sosial 0.360 di mana nilai Sig $>0.05$. Dengan demikian dapat disimpulkan bahwa variabel tersebut dikatakan memiliki data yang tidak heteroskedastisitas atau dapat dikatakan terjadi persamaan varians residual pada aitem regulasi emosi dan dukungan sosial pada setiap pengamatan satu ke pengamatan yang lain.

Berdasarkan hasil uji korelasional ganda yang dilakukan menggunakan Pearson Product Moment didapatkan hasil Sig. 2-tailed pada variabel regulasi emosi 0.000 dan pada variabel dukungan sosial 0.008 Keduanya memenuhi kaidah korelasional Sig. (2tailed) $<0.05$.

Tabel 11. Hasil Uji Korelasional Ganda

\begin{tabular}{cc}
\hline Variabel & Sig. (2-Tailed) \\
\hline Regulasi Emosi & .000 \\
Dukungan Sosial & .008
\end{tabular}

Tabel 11 menunjukkan bahwa: hasil uji korelasional ganda yang dilakukan membuktikan adanya hubungan korelasional antar variabel yaitu regulasi emosi berkorelasi dengan ide bunuh diri begitu juga dukungan sosial berkorelasi dengan ide bunuh diri. Selanjutnya untuk menguji hipotesis yang dirumuskan di dalam penelitian ini, analisis stataistik yang digunakan adalah analisis regresi, hasilnya ditunjukkan pada tabel 12 berikut:

Tabel 12. Hasil Uji Analisis Regresi Linear Berganda

\begin{tabular}{lcccc}
\hline Variabel & Koefisien Regresi & Std Error & Thitung & Sig \\
\hline Konstanta & 35.318 & 2.114 & 16.708 & 0.000 \\
Regulasi Emosi & -0.361 & 0.052 & -6.894 & 0.000 \\
Dukungan Sosial & -0.125 & 0.047 & -2.658 & 0.008 \\
$\mathrm{R}$ & $.629^{\mathrm{a}}$ & & & \\
$\mathrm{R}^{2}$ & 0.396 & & & \\
Adjusted R $^{2}$ & 0.390 & & & $.000^{\mathrm{b}}$ \\
$\mathrm{F}$ & 67.796 & & Ide Bunuh \\
Variabel Dependen & & & Diri \\
\hline
\end{tabular}


Berdasarkan tabel 12 yakni hasil uji analisis regresi linear berganda diperoleh penjelasan sebagai berikut; (1) Nilai konstanta sebesar 35.518 menyatakan bahwa variabel regulasi emosi dan dukungan sosial tidak berubah, maka nilai ide bunuh diri adalah sebesar 35.518, (2) Nilai koefisien dari regulasi emosi sebesar -0.361 menandakan bahwa terdapat arah negatif, ketika ide bunuh diri mengalami kenaikan sebesar 1 satuan maka nilai regulasi emosi akan turun sebesar 0.361, dan ketika nilai ide bunuh diri mengalami penurunan sebesar 1 satuan maka nilai dari regulasi emosi juga akan naik sebesar 0.361, (3) Nilai koefisien pada dukungan sosial sebesar 0.125 menandakan adanya arah yang negatif. Ketika variabel ide bunuh diri turun sebesar 1 satuan maka akan diikuti oleh kenaikan dari variabel dukungan sosial sebesar 0.125 , dan begitu juga ketika variabel ide bunuh diri mengalami kenaikan sebesar 1 satuan maka nilai dari variabel dukungan sosial juga akan turun sebesar 0.125

Uji analisis regresi diperoleh nilai t hitung sebesar 0.000 pada variabel regulasi emosi dan 0.008 pada variabel dukungan sosial. Nilai t hitung dari masing-masing variabel yaitu variabel regulasi emosi $0.000<0.05$ sehingga dapat dikatakan bahwa variabel regulasi emosi memiliki pengaruh yang signifikan terhadap variabel ide bunuh diri, sedangkan pada variabel dukungan sosial dengan signifikansi $0.008<0.05$, sehingga dapat dikatakan bahwa variabel dukungan sosial memiliki pengaruh yang signifikan terhadap ide bunuh diri. Penelitian ini juga membuktikan bahwa: hasil nilai f-hitung sebesar $0.000<0.05$, sehingga dapat disimpulkan bahwa variabel regulasi emosi dan variabel dukungan sosial secara bersama-sama memiliki pengaruh yang signifikan terhadap ide bunuh diri. Didapatkan nilai $\mathrm{R}^{2} 0.396$, artinya variabel regulasi emosi dan dukungan sosial memiliki pengaruh terhadap ide bunuh diri sebesar 39.62\%. Sumbangan efektif regulasi emosi adalah sebesar $30.04 \%$, sementara itu sumbangan efektif dukungan sosial sebesar $9.58 \%$. Temuan penelitian ini membuktikan bahwa sumbangan efektif regeluasi emosi terhadap ide bunuh diri lebih dominan dibandingkan dengan dukungan sosial yang diperoleh.

\section{PEMBAHASAN}

Hasil penelitian membuktikan bahwa ada pengaruh negatif regulasi emosi terhadap ide bunuh diri khususnya pada responden mahasiswa. Hasil penelitian ini relevan dengan kajian teori yang ada, bahwa regulasi emosi merujuk pada kemampuan untuk membentuk dan atau mengenali emosi apa yang dimiliki individu kapan individu tersebut memiliki atau memunculkan emosi tersebut, dan bagaimana individu tersebut mengalami dan atau mengekspresikan emosi tersebut (Gross, 2014). Kemampuan regulasi emosi berkaitan dengan bagaimana individu dapat mengelola dan memahami ekspresi emosi yang dialami. Ketika seseorang dapat melakukan regulasi emosi, maka akan dapat meningkatkan atau menurunkan efek dari emosi positif atau negatif yang muncul dalam situasi dan kondisi tertentu. 
Di dalam proses regulasi emosi, terdapat manajemen pengelolaan emosi positif dan negatif yang dapat muncul sewaktu-waktu, terutama berkaitan dengan ketika seorang individu dihadapkan pada situasi dan kondisi yang dapat mengakibatkan munculnya emosi negatif. Ketidakmampuan dalam mengelola emosi negatif inilah yang nantinya dapat membuat individu ketika mengalami tekanan berat yang dapat merujuk pada depresi dan bahkan perilaku bunuh diri. Hasil penelitian membuktikan bahwa ketika dihadapkan pada suatu situasi yang mungkin memunculkan emosi negatif, beberapa orang dapat mengatasi dan mengatur emosinya sehingga mereka tidak akan terkait dengan perilaku bunuh diri, akan tetapi beberapa orang lainnya yang kurang dapat meregulasi emosinya dapat termotivasi dan lebih mungkin untuk memiliki dorongan dan gagasan untuk melakukan bunuh diri (Bazrafshan dkk., 2014).

Sejalan dengan penelitian sebelumnya (Rajappa dkk., 2012b), disebutkan bahwa individu yang bermasalah dengan regulasi emosinya dapat meningkatkan kemungkinan resiko terjadinya perilaku bunuh diri Hasil penelitian menunjukkan bahwa kurangnya kemampuan regulasi emosi secara signifikan dapat memprediksi muncul atau tidaknya ide bunuh diri. Hasil dalam penelitian tersebut mengindikasikan bahwa kurangnya akses terhadap kemampuan strategi regulasi emosi menjadi salah satu aspek terjadinya disregulasi emosi yang secara kuat berhubungan dengan pemikiran untuk melakukan bunuh diri (Wagner \& Zimmerman, 2006).

Penelitian sebelumnya (Ong \& Thompson, 2019b) juga menguatkan hasil penelitian ini bahwa regulasi emosi memiliki kaitan dengan perilaku bunuh diri. Dikatakan bahwa ketika seseorang gagal dalam mengadopsi atau tidak menerima suatu respon emosional tertentu, hal ini berarti individu mengalami kegagalan dalam penerapan regulasi emosinya, kemudian secara signifikan dapat meningkatkan prediksi adanya pemikiran untuk melakukan bunuh diri. Hasil penelitian menguatkan penelitian ini, bahwa meningkatnya koping dengan cara menghindar berhubungan dengan meningkatnya perilaku bunuh diri, sementara meningkatnya regulasi emosi dengan strategi cognitive reappraisal berhubungan dengan berkurangnya resiko perilaku bunuh diri (Ong \& Thompson, 2019b).

Berkaitan dengan subjek pada penelitian ini yaitu mahasiswa akhir, ditemukan bahwa ketika mahasiswa akhir dihadapkan pada suatu kondisi yang dapat memunculkan emosi negatif yang diakibatkan oleh beban dan tekanan yang dimiliki dan yang bersangkutan tidak dapat meregulasi emosinya, maka hal tersebut dapat meningkatkan resiko munculnya perilaku bunuh diri berupa pemikiran atau ide bunuh diri. Penelitian ini menemukan bahwa dari 210 subjek, sebanyak 82 orang subjek (39.04 \%) memiliki kemampuan regulasi emosi sedang, dan 1 orang subjek memiliki kemampuan regulasi emosi yang rendah. Artinya, masih cukup banyak mahasiswa yang memiliki resiko untuk mengalami disregulasi emosi, yang bisa berpeluang memunculkan beberapa resiko yang dapat mengarah pada meningkatnya pemikiran untuk bunuh diri. Jika dihubungkan dengan ide bunuh diri, hal ini dikatakan memiliki pengaruh yang signifikan karena dari 
keseluruhan jumlah subjek, ditemukan hasil bahwa tahapan ide bunuh diri yang dialami oleh para subjek beragam, dan tidak hanya ditemukan pada tahapan awal saja yaitu kemunculan ide bunuh diri yang diakibatkan oleh munculnya rasa sakit fisik dan psikis dan hilangnya kemampuan untuk mengatasi hal tersebut, tetapi juga ditemukan bahwa subjek memiliki ide yang menguat terjadi pada (80\%) responden dan terdapat $(6 \%)$ responden yang memiliki kesiapan untuk melakukan percobaan bunuh diri.

Hasil penelitian membuktikan ada pengaruh secara negatif berarti ketika nilai dukungan sosial naik maka ide bunuh diri akan turun, begitu juga sebaliknya ketika dukungan sosial turun maka ide bunuh diri akan naik. Temuan ini memiliki kesesuaian dengan hasil kajian teori yang ada, bahwa dukungan sosial merujuk pada sebuah tindakan yang memberikan kenyamanan, kepedulian, penghargaan, dan bantuan kepada orang lain ataupun kelompok Konsep dukungan sosial merupakan interaksi dan sumber (resources) yang diberikan individu untuk individu lain dalam menghadapi problematik Wills \& Filer-Fegan (Baum dkk., 2011). Hasil penelitian (Miller dkk., 2015) membuktikan bahwa kurangnya dukungan sosial (dalam penelitian ini dukungan yang dimaksud adalah dari orangtua dan teman dekat) pada siswa secara signifikan dapat memprediksi tingginya kemungkinan siswa tersebut untuk memiliki gagasan atau ide melakukan bunuh diri, bahkan sampai menunjukkan perilaku percobaan bunuh diri. Hal ini dikaitkan dengan adanya masalah yang mungkin sedang dihadapi oleh siswa tersebut, akan tetapi tidak diimbangi dengan adanya dukungan sosial yang diterima sehingga memunculkan tekanan yang akhirnya merujuk pada perilaku bunuh diri berupa ide dan bahkan percobaan bunuh diri. Kondisi ini relevan dengan penelitian yang dilakukan oleh Hovey dan King (Reynolds \& Mazza, 1999b) ditemukan hasil bahwa skor dukungan sosial yang rendah berkorelasi dengan tingginya angka skor depresi yang berhubungan dengan munculnya ide untuk melakukan bunuh diri.

Hasil penelitian ini membuktikan bahwa dukungan sosial yang diterima oleh subjek (mahasiswa) mayoritas berada pada kategori sedang. Sebanyak 131 mahasiswa $(62.39 \%)$ menerima dukungan sosial yang berada pada kategori sedang artinya merujuk pada data ini cukup banyak mhasiswa yang beresiko yang mengarah pada munculnya ide bunuh diri jika suatu saat dihadapkan dengan tekanan, sementara dukungan yang diterima tidak cukup kuat, berperan sebagai buffering effect munculnya ide bunuh diri.

Hasil penelitian menunjukkan bahwa secara simultan regulasi emosi dan dukungan social berpengaruh terhadap ide bunuh diri pada mahasiswa, dengan besaran sumbangan efektif sebesar 39.62\% terhadap ide bunuh diri. Data menunjukkan regulasi emosi memiliki sumbangan efektif yang lebih besar (30.04\%) dibandingkan dengan dukungan sosial $(9.58 \%$ ) dalam memprediksi munculnya ide bunuh diri pada responden mahasiswa.

Hasil penelitian membuktikan peran regulasi emosi dan dukungan sosial terhadap ide bunuh diri, sejalan dan relevan dengan hasil penelitian sebelumnya. Hasil penelitian John \& Gross (dalam Ong \& Thompson, 2015) menyebutkan terdapat beberapa faktor 
resiko yang dapat meningkatkan munculnya ide bunuh diri, termasuk di dalamnya yaitu: depresi, kemampuan koping yang terbatas atau buruk, tingginya perilaku menghindar dari stressor dan kurangnya relasi sosial yang dekat. Kemampuan regulasi emosi dan adanya dukungan sosial ini akan berpengaruh terhadap kemampuan koping dan keberhasilannya. Artinya bahwa ketika seseorang gagal dalam mengadopsi strategi regulasi emosi dan penolakan terhadap respon emosional, maka secara signifikan dapat menjadi prediktor munculnya ide bunuh diri. Rajappa (dalam Ong \& Thompson, 2015) menyebutkan bahwa perilaku bunuh diri (ide bunuh diri) muncul saat seseorang mencoba untuk menghindar dari emosi negatif dan semakin menguat saat strategi regulasi emosi yang digunakan untuk merespon distress emosional tersebut kurang memadai. Selain itu, ketika dihadapkan pada situasi tersebut, dukungan dari lingkungan sosial memiliki peran cukup besar dalam membantu seseorang keluar dari stres dan depresi yang dirasakannya. Kurang adanya dukungan dari lingkungan menyebabkan individu melakukan percobaan bunuh diri berulang kali. Dengan tidak adanya dukungan sosial yang diterima, maka ketika individu yang mengalami stres dan depresi memiliki resiko semakin kuat untuk memunculkan gagasan untuk bunuh diri (Mukarromah \& Nuqul, 2014).

Terkait dengan konteks subjek penelitian, khususnya di kalangan mahasiswa Universitas Negeri Malang, fenomena ide bunuh diri cukup banyak dialami oleh mahasiswa. Tekanan yang bisa diakibatkan oleh banyak hal baik berupa tekanan akademik, tekanan sosial, masalah pribadi, dan lain sebagainya dapat memunculkan ide bunuh diri pada komunitas ini. Hal tersebut dapat disimpulkan dari hasil penelitian yang menguatkan fakta bahwa kemampuan regulasi emosi mahasiswa berada pada kategori sedang dan dukungan sosial yang dirasakan pada kategori cukup, memungkinkan dapat menimbulkan resiko munculnya ide bunuh diri. Mayoritas subjek memiliki ide bunuh diri pada tahapan kedua dimana ide semakin menguat diakibatkan oleh ketidakmampuan berbagi rasa sakit pada orang lain. Dengan kata lain dapat disimpulkan bahwa kemampuan regulasi emosi yang dimiliki dan dukungan sosial yang diterima masih belum cukup untuk dapat mereduksi munculnya ide bunuh diri atau belum cukup menjadi 'buffering effect'.

Pembahasan mengenai temuan dalam penelitian ini dapat dijelaskan secara teoritik terkait dengan faktor yang mendasari munculnya ide bunuh diri. Disebutkan oleh Klonsky, dkk (2016) dalam faktor-faktor penyebab munculnya ide bunuh diri baik regulasi emosi dan dukungan sosial muncul secara konsisten. Faktor pertama yaitu adanya tekanan berat disertai dengan ketiadaan relasi, dapat dipahami bahwa ketika tidak ada dukungan dari lingkungan sosial apakah itu dari teman, relasi, lingkungan social, ketika individu mengalami tekanan berat, yang dapat memunculkan munculnya ide bunuh diri. Hasil penelitian ini memberikan informasi yang menarik bahwa subjek memiliki ide bunuh diri di tahapan kedua, yaitu ketidakmampuan dalam berbagi "rasa sakit" pada relasi dan orang lain. Sejalan dengan faktor yang telah dijelaskan sebelumnya, subjek mengalami tekanan berat, tetapi ketiadaaan relasi menyebabkan subjek tidak dapat 
berbagi mengenai rasa sakit yang diakibatkan oleh tekanan berat yang dimiliki sehingga ide bunuh diri muncul. Hasil penelitian juga memberikan informasi bahwa sebagian besar subjek memiliki dukungan sosial yang cukup akan tetapi di sisi lain data juga menunjukkan adanya kemunculan ide bunuh diri. Hal ini berarti bahwa dukungan sosial yang diterima bisa dikatakan belum cukup efektif, dan berperan sebagai faktor yang menguatkan individu dalam meminimalkan ide bunuh diri.

Berkaitan dengan faktor kedua dan ketiga yang menyatakan mengenai rasa putus asa dan kombinasi dari rasa sakit dan kesepian, disebutkan oleh Klonsky, dkk (2016) bahwa individu tidak dapat mengelola atau meregulasi emosinya sehingga rasa sakit baik fisik maupun psikis mulai muncul sehingga membuat individu merasa putus asa dan terperangkap oleh rasa sakit tersebut sehingga ide bunuh diri lalu muncul. Data ini dikuatkan dengan data deskriftif bahwa mayoritas subjek memang memiliki kemampuan regulasi emosi sedang, di sisi lain ditemukan hasil bahwa mayoritas subjek memiliki ide bunuh diri pada tahapan kedua. Hal ini berarti kuat dugaan kemampuan regulasi emosi belum efektif untuk mereduksi rasa sakit yang ditimbulkan oleh situasi yang menekan, sehingga ide bunuh diri tetap muncul. Ringkas kata, regulasi emosi dan dukungan sosial merupakan predictor yang berperan munculnya ide bunuh diri pada mahasiswa.

\section{SIMPULAN}

Hasil analisis data deskriftif menunjukkan bahwa: (1) Sebagian besar regulasi emosi berada pada kategori tinggi khusunya menggunakan strategi cognitive reappraisal. Sebagian besar responden memperoleh dukungan sosial pada kategori sedang, namun bentuk dukungan yang masih dirasakan kurang adalah dalam bentuk self-esteem support dan belonging support. Sebagian besar responden memiliki ide bunuh diri kategori sedang, artinya individu memiliki ide bunuh diri yang dimungkinkan menguat bila individu tidak bisa berbagi dan menceritakan tekanan yang dialami pada orang lain. (2) Regulasi emosi memiliki pengaruh negatif terhadap ide bunuh diri pada mahasiswa, (3) Dukungan sosial memiliki pengaruh negatif terhadap ide bunuh diri pada mahasiswa (4) Regulasi emosi dan dukungan sosial secara simultan berpengaruh terhadap ide bunuh diri pada mahasiswa (5) Regulasi emosi dan dukungan sosial memiliki kontribusi efektif terhadap ide bunuh diri. Selain itu, sumbangan efektif regulasi emosi lebih besar dibandingkan dukungan sosial.

\section{REKOMENDASI}

Merujuk pada temuan penelitian, penting bagi mahasiswa untuk dapat memahami emosinya agar manifestasi dari emosi yang muncul dapat terekspresikan dengan efektif, terutama ketika dihadapkan pada situasi dan kondisi yang memicu emosi negatif (sedih, marah, stres dan depresi) karena kepiawaian dalam meregulasi emosi merupakan faktor peredam munculnya ide bunuh diri, meskipun dukungan sosial juga dibutuhan untuk 
meminimalkan ide bunuh diri, utamanya self-esteem support dan belonging support dari orang "penting" (keluarga, pasangan dan teman).

Regulasi emosi lebih kuat perannya sebagai predictor munculnya ide bunuh diri, oleh karena itu penting bagi Institusi Pendidikan untuk memberikan emotion regulation training khususnya pada mahasiswa dengan resiko tinggi yang mengarah pada ide bunuh diri. Bagi peneliti selanjutnya yang ingin melakukan penelitian dengan topik serupa diharapkan untuk dapat melakukan penelitian dengan sampel yang lebih beragam utamanya pada college age. Selain itu untuk penelitian selanjutnya, dapat dikembangakan desain penelitian yaitu desain penelitian eksperimen untuk menguji pengaruh emotion regulation training untuk mengurangi ide bunuh diri, khususnya pada mahasiswa yang beresiko tinggi.

\section{DAFTAR PUSTAKA}

Baum, A., Revenson, T. A., \& Singer, J. (2011). Handbook of Health Psychology (2nd Editio). Psychology Press. https://doi.org/10.4324/9780203804100

Bazrafshan, M.-R., Jahangir, F., Mansouri, A., \& Kashfi, S. H. (2014). Coping Strategies in People Attempting Suicide. Int J High Risk Behav Addict, 3(1), 16265. https://doi.org/10.5812/ijhrba.16265

Beaton, D. E., Bombardier, C., Guillemin, F., \& Ferraz, M. B. (2000). Guidelines for the Process of Cross-Cultural Adaptation of Self-Report Measures. SPINE, 25, 31863191.

Cohen, S., \& Hoberman, H. M. (1983). Life Change Stress' $m$ a 1. Journal of Applied Social Psychology, 13(2), 99-125.

Gross, J. J. (2014). Handbook of Emotion Regulation (J. J. Gross, Ed.; Second Edi). THE GUIL FORD PRESS.

Gross, J. J., \& John, O. P. (2003). Individual Differences in Two Emotion Regulation Processes: Implications for Affect, Relationships, and Well-Being. Journal of Personality and Social Psychology, 85(2), 348-362. https://doi.org/10.1037/0022-3514.85.2.348

John, O., \& Gross, J. (2004). Healthy and unhealthy emotion regulation: Personality processes, individual .... Journal of Personality, 72(6), 1301-1334.

Kimbrough, R. M., Molock, S. D., \& Walton, K. (1996). Perception of social support, acculturation, depression, and suicidal ideation among African American college students at predominantly Black and predominantly White universities. Journal of Negro Education, 65(3), 295-307.

Klonsky, D. E., \& May, A. M. (2015). The three-step theory (3ST): A new theory of suicide rooted in the "ideation-to-action" framework. International Journal of Cognitive Therapy, 8(2), 114-129. https://doi.org/10.1521/ijct.2015.8.2.114

Miller, A. B., Esposito-Smythers, C., \& Leichtweis, R. N. (2015). Role of social support in adolescent suicidal ideation and suicide attempts. Journal of Adolescent Health, 56(3), 286-292. https://doi.org/10.1016/j.jadohealth.2014.10.265 
Miranda, D., Gaudreau, P., Debrosse, R., Morizot, J., \& Kirmayer, L. J. (2012). Music Listening and Mental Health: Variations on Internalizing Psychopathology. Music and Internalizing Psychopathology, 513-529.

Ong, E., \& Thompson, C. (2019a). The Importance of Coping and Emotion Regulation in the Occurrence of Suicidal Behavior. Psychological Reports, 122(4), 11921210. https://doi.org/10.1177/0033294118781855

Ong, E., \& Thompson, C. (2019b). The Importance of Coping and Emotion Regulation in the Occurrence of Suicidal Behavior. Psychological Reports, 122(4), 11921210. https://doi.org/10.1177/0033294118781855

Pereira, A., \& Cardoso, F. (2015). Suicidal ideation in university students: Prevalence and association with school and gender. Paideia, 25(62), 299-306. https://doi.org/10.1590/1982-43272562201503

Rajappa, K., Gallagher, M., \& Miranda, R. (2012a). Emotion dysregulation and vulnerability to suicidal ideation and attempts. Cognitive Therapy and Research, 36(6), 833-839. https://doi.org/10.1007/s10608-011-9419-2

Rajappa, K., Gallagher, M., \& Miranda, R. (2012b). Emotion dysregulation and vulnerability to suicidal ideation and attempts. Cognitive Therapy and Research, 36(6), 833-839. https://doi.org/10.1007/s10608-011-9419-2

Reber, A. S., \& Reber, E. S. (2010). Kamus psikologi. Pustaka Pelajar.

Reynolds, W. M., \& Mazza, J. J. (1999a). Assessment of suicidal ideation in inner-city children and young adolescents: Reliability and validity of the suicidal ideation questionnaire-JR. School Psychology Review, 28(1), 17-30. https://doi.org/10.1080/02796015.1999.12085945

Reynolds, W. M., \& Mazza, J. J. (1999b). Assessment of suicidal ideation in inner-city children and young adolescents: Reliability and validity of the suicidal ideation questionnaire-JR. School Psychology Review, 28(1), 17-30. https://doi.org/10.1080/02796015.1999.12085945

Salsabhilla, A., \& Panjaitan, R. U. (2019). Dukungan Sosial Dan Hubungannya Dengan Ide Bunuh Diri Pada Mahasiswa Rantau. Jurnal Keperawatan Jiwa, 7(1), 107. https://doi.org/10.26714/jkj.7.1.2019.107-114

Sugiyono. (2016). Statistika Penelitian. CV Alfabeta Bandung.

Sugiyono. (2018). Metode Penelitian Kuantitatif. Penerbit Alfabeta.

Wagner, B. M., \& Zimmerman, J. H. (2006). Developmental Influences on Suicidality Among Adolescents: Cognitive, Emotional, and Neuroscience Aspects. Dalam American Psychological Association (hlm. 287-308). https://doi.org/10.1037/11377-013

Wilcox, H. C., Arria, A. M., Caldeira, K. M., Kathryn, B., Pinchevsky, G. M., \& Grady, K. E. O. (2011). And Attempts During College. 127, 287-294. https://doi.org/10.1016/j.jad.2010.04.017.Prevalence 